\title{
The Martial Spirit-Naval Style: The Naval Reform Movement and the Establishment of the General Board of the Navy, 1873 - 1900.
}

\section{John T. Kuehn}

Le conseil général de la marine était un organisme purement américain, conçu pour la planification stratégique et opérationnelle, sans antécédents aux Etats-Unis et avec peu d'homologues dans d'autres pays. Cet essai trouve que les facteurs qui ont contribué à la fondation du conseil général reflètent une professionnalisation continue du corps d'officiers de la marine nationale des États-Unis et démontre également que la période de ces changements-1880-1900-représente une période de réforme et d'innovation qui préfigure et précède "la révolution des cuirassés " mieux connue. En particulier, l'élément généralement moins étudié mais primordial à ce récit concerne la façon par laquelle la marine des États-Unis a utilisé le modèle de la Kriegsakademie allemande comme un moyen de formation des officiers ainsi que l'institution et la pratique de procédures générales pour le personnel au sein de l'école de guerre maritime, le bureau de renseignements navals, et le bureau du secrétaire adjoint de la marine nationale.

The General Board of the Navy was a uniquely American strategic and operational planning organization with no antecedents in the United States and few counterparts in other nations. It was established by executive fiat in 1900 in response to a changing and complex world and was similarly disestablished in early 1951 at the advent of the Cold War-shortly after the major defense reforms in the years after World War II. This essay finds that the factors that contributed to the founding of the General Board reflected an ongoing professionalization of the officer corps of the U.S. Navy. This professionalism often advanced under the banner of reform. Naval professionalism in turn became a component of a larger "martial spirit" that had come to grip the United States in the late $19^{\text {th }}$ century, although in many respects it pre-figured and ante-dated a rising general trend toward a more military-friendly attitude by the American political elites and population at large. The paper also posits, tangentially, that the period of these changes - 1880-1900 - represents a period of reform and innovation that both prefigures and predates the more well-known and written about "Dreadnought Revolution" engineered by Britain's Sir John "Jacky" Fisher in the early $20^{\text {th }}$ Century.

At the time of the General Board's establishment, there were no permanent general staffs in the United States. This was a direct reflection of the anti-military heritage of the United States, derived from Great Britain's own experience and distaste 
for standing armies and military dictators (like Oliver Cromwell) as well as the young republic's own perceived experience as a mistreated British colony. ${ }^{1}$ The Constitution of the United States specifically enjoined against the raising of permanent armies for more than two years and Bill of Rights amendments II and III enshrine a militia and eschew military quartering, respectively. However, the same Constitution permitted the establishment and maintenance of a Navy-without codicils. When the precursor of a professional general staff emerged in the United States in the last half of the $19^{\text {th }}$ century, it emerged in the Navy Department not in the War Department or the United States Army.

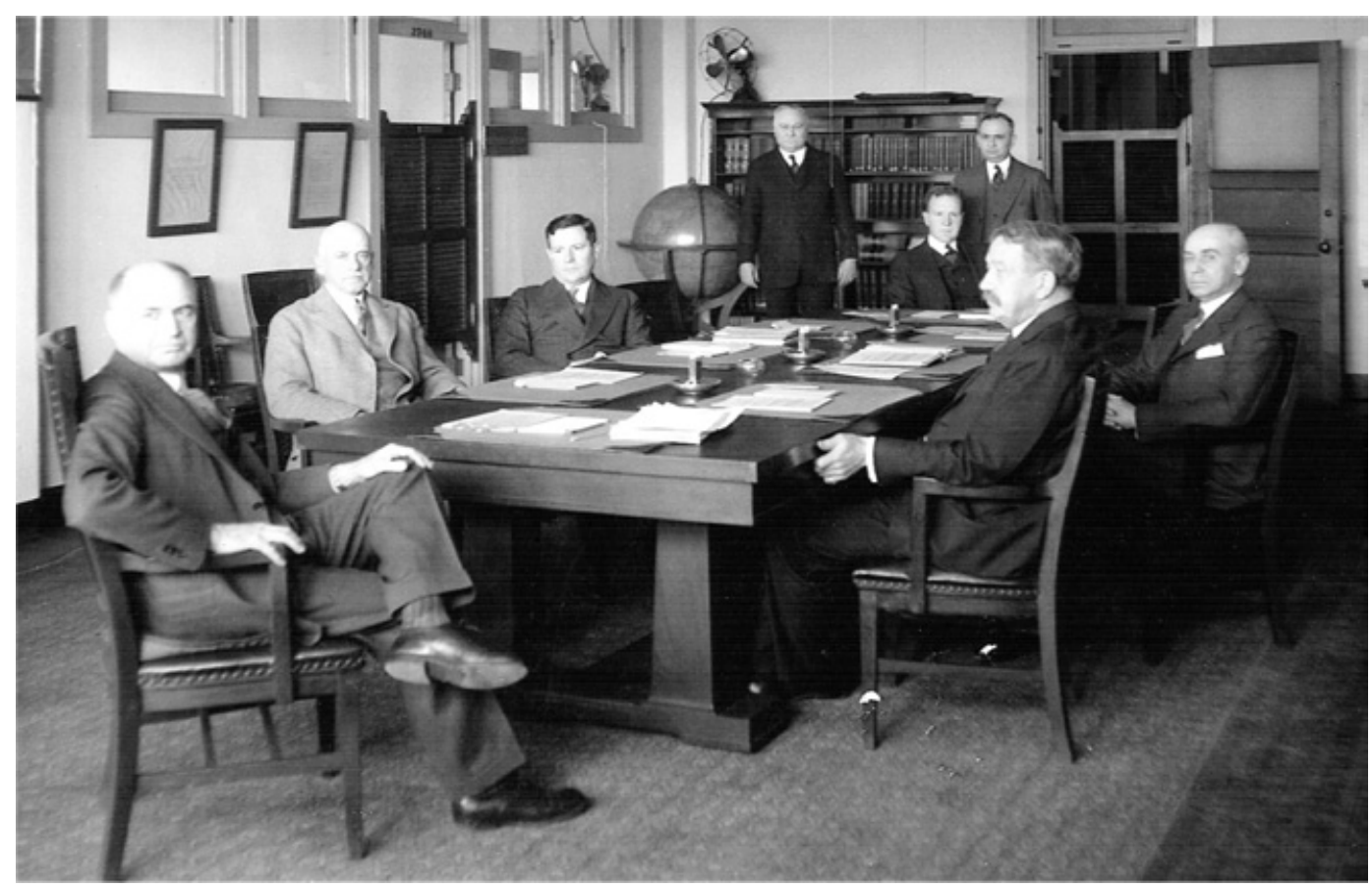

Illustration1: The General Board in 1932 in the old Army-Navy Building. Note the civilian dress. Photo NH 50175, courtesy of the Naval Historical Center.

In 1931 journalist Walter Millis published The Martial Spirit, a revisionist and critical account of the events leading up to and through the Spanish American War in 1898. Millis's important book on the martial spirit reflected a thoughtful reappraisal of the development of a uniquely American form of militarism tied to America's expansionist foreign policy - the two were inter-related and interdependent. Often touted as "jingoism" for foreign policy and "navalism" when applied to the policies and writings of Theodore Roosevelt and A.T. Mahan, this spirit encompassed those tendencies. Other observers, both contemporary and subsequently have also identified these emerging

This best exposition on the anti-military tradition of Americans can be found in Samuel Huntington, The Soldier and the State (Cambridge, MA: Harvard University Press, 1957), chapter 4 passim, especially 97-98. 
attitudes. $^{2}$ Navalism, in particular, is a term that came to have a pejorative meaning, especially given the hindsight after World War I and the common perception of the prewar naval arms as one of the major causes of its outbreak. ${ }^{3}$ It is against this larger background of a transformation in the civic attitudes of the American polity and public (these two are not the same) that the naval reforms leading establishment of the General Board of the Navy must be examined.

The establishment of an organization to help the Navy secretary plan for war (among other things) also had its roots in the trends and developments of the Progressive Era of the late $19^{\text {th }}$ and early $20^{\text {th }}$ centuries. Its creation was very much a reflection of the reformist spirit of the times that would later give birth to the Army War College, the Army General Staff, and the Chief of Naval Operations. ${ }^{4}$ Another trend that contributed to the establishment of a general staff that predates Millis's martial spirit has to do with American naval officers' long history of desiring a greater role in the planning and use of the fleet. ${ }^{5}$ As with most reform, the impetus came from recent experience, lessons learned "the hard way" in a war. ${ }^{6}$ Out of the hard lessons and mismanagement of the War of 1812 Congress authorized a Board of Navy Commissioners in 1815 composed of three post captains. This was not what the officer corps wanted, since the scope for this board was administrative and not operational. Operational employment of the fleet remained firmly in civilian hands. The creation of the board of commissioners was, however, a foot in the door because their work, and the organizational precedent established, led to the establishment of the Navy bureau system in 1842. However, the fundamental purpose

2 Walter Millis, The Martial Spirit: A Study of Our War with Spain (Boston, MA: Houghton Mifflin company, 1931), see especially pages 407-410. For navalism see especially Peter Karsten, The Naval Aristocracy: The Golden Age of Annapolis and the Emergence of Modern American Navalism (New York: The Free Press, 1972); for the classic exposition after World War I see Harold and Margaret Sprout, Toward a New Order of Sea Power: American Naval Policy and the World Scene, 1918 - 1922 (Princeton, NJ: Princeton UP, 1940), for a more recent synthesis see Lisle Rose, Power At Sea: The Age of Navalism, 18901981 (Columbia, MO: University of Missouri Press, 2006).

3 Senate Document No. 77, "Address of the President of the United States at the Opening of the Conference on the Limitation of Armament at Washington, November 21, 1921" (Washington: Government Printing Office, 1921), 6-7. Indirect evidence existed prior to the war's end in point four of Woodrow Wilson's famous "14 Points" speech to Congress, http://www.firstworldwar.com/source/fourteenpoints.htm (accessed 7/17/2011).

$4 \quad$ Philip L. Semsch, "Elihu Root and the General Staff," Military Affairs vol. 27, no. 1 (Spring 1963), 16-27; Ronald H. Spector, Professors at War: The Naval War College and the Development of the Naval Profession (Newport, RI: Naval War College Press, 1977), 1-3, n.11, 152. Spector makes a direct link between organizational reform in the Navy as a subset of the larger societal trends and developments, especially the Navy's quest for "efficiency" and the Navy's "business approach to war." See also Robert H. Wiebe The Search for Order, 1877-1920 (New York: Hill and Wang, 1967) for a concise history of the Progressive Era.

5 My arguments here follow almost entirely from Henry P. Beers seminal and still useful article "The Development of the Office of the chief of Naval Operations, Part I," Military Affairs vol. 10, no. 1 (Spring, 1946), 40-68.

6 Williamson Murray and Alan Millett, "Innovation: Past and Future," in Military Innovation in the Interwar Period (Cambridge: Cambridge University Press, 1996), 313-314. The authors dispel the axiom that we should not study to fight the last war and replace it with one that proposes an honest study of conflict, including "the last war." 
of the bureaus remained administrative and reflected the attitude that "no special experience or knowledge was required for the direction of the fleet...." Professional knowledge was only really needed for building and maintaining the fleet. ${ }^{7}$

During the Civil War further operational reform occurred, but only on the civilian side. Abraham Lincoln and Secretary of the Navy Gideon Welles soon recognized the need for naval expertise and created what might be termed operational control by civilian proxy when they established the position of the Assistant Secretary of the Navy. In this new office they placed the former naval officer Gustavus Vasa Fox. Most naval historians characterize Fox's actions as those of a de facto if not de jure Chief of Naval Operations. Under Fox's competent leadership the seed kernel for a planning organization was created with the expansion of the bureau system from five to eight during the war, including the significant creation of the Bureau of Navigation. ${ }^{8}$ Meanwhile the bureaus developed into powerful bureaucracies in their own right that came to impede the reformers' desire for an operational and even strategic voice at the highest policy levels. The war's conclusion (and perhaps Lincoln's death) nullified many of these gains as they pertain to the establishment of an operational planning organization composed of active duty officers. The position of Assistant Secretary of the Navy was abolished (1869) and Admiral David Farragut's efforts to establish a Board of Admiralty along British lines was also defeated in Congress. The Navy was reduced and went from being the second largest fleet in the world to the smallest among the major powers. ${ }^{9}$ Historian Frederick Jackson Turner's "frontiers" did not yet include command of the seas and the naval martial spirit would have to find expression at some later date. ${ }^{10}$

\section{The First Phase Reform: 1879-1898}

Reforms came, but not all at once. The years of reconstruction and the "taming" of Jackson Turner's frontier took several decades. Despite the years of seeming stasis between 1865 and 1881, events and personalities were casting the mold of the shapes of things to come. Civil War Admiral David Dixon Porter worked against a backdrop of neglect and infighting between line and staff officers (the latter included engineers) through the hero of the famous Merrimac-Monitor encounter, Commodore John Worden, Superintendent of the U.S. Naval Academy. ${ }^{11}$ In 1873 Worden and several other naval officers founded a professional association - the United States Naval Institute (USNI),

$7 \quad$ Henry P. Beers, "The Development of the Office of the Chief of Naval Operations," Military Affairs vol. 10, no. 1 (Spring, 1946), 41-42. The reformers wanted seven bureaus but got only five: Yards and Docks; Construction Equipment and Repairs; Provisions and Clothing; Ordinance and Hydrography; and Medicine.

$8 \quad$ Ibid., 44. For assessments of Fox as a proto-chief of naval operations see Ari Hoogenboom, Gustavus Vasa Fox of the Union Navy: A Biography (Baltimore, MD: Johns Hopkins University Press, 2009), ix; and Craig L. Symonds, Lincoln and His Admirals: Abraham Lincoln, the U.S. Navy, and the Civil War (New York, Oxford University Press, 2008), xiv.

9 The Navy decreased from 700 warships to just 48. Beers, 44-45.

10 For the famous "Frontier Thesis," see Frederick Jackson Turner, "The Significance of the Frontier in American History," in Martin Ridge, ed., Frederick Jackson Turner: Wisconsin's Historian of the Frontier (Madison: State Historical Society of Wisconsin,1986).

11 Robert W. Love, Jr. History of the U.S. Navy, 1775-1941 (Harrisburg, PA: Stackpole Books, 1992), 327-330. 
reputedly the third stage in the professionalization of a group. This organization was formed for "the advancement of professional, literary, and scientific knowledge in the naval and maritime services, and the advancement of the knowledge of sea power." 12

Early in 1879 winds of change could be detected blowing when founding UNSI member Rear Admiral Daniel Ammen authored a significant essay entitled "The Purposes of a Navy, and the Best Methods of Rendering it Efficient." Ammen, a boyhood friend of President U.S. Grant from Ohio, had served with distinction in the Civil War at the battle of Port Royal (1861) and both assaults on Fort Fisher (1864). ${ }^{13}$ Ammen articulated the long-held opinion of naval officers in favor of education, but his remarks at the essay's end also pointed to the need for preparation and war planning in peace:

It seems worth while for us neither to be fixed in the idea that we have reached a state of comparative permanency, nor on the other hand to expect to rely upon supposititious and untried developments of naval strength. The time of peace, however, is the time to design and test whatever seems calculated to make naval warfare formidable, destructive and economic, remembering that nothing is economic that is not effective. ...Courage is a natural quality, far more common than many suppose, - at least sufficient courage to do a recognized duty; but that alone will not suffice. [emphases mine $]^{14}$

That same year the Record (later the Proceedings) of the Naval Institute began quarterly publication and the awarding of money for an annual prize essay competition, in part due to the lobbying of several members including Commander A.T. Mahan. The Institute chose "Naval education" as the first topic for this new annual competition. Mahan was now head of the Ordnance Department at the Naval Academy (and so colocated with offices of USNI). Mahan's own essay on naval education won third prize, but it was his first article and a visible portent of the move toward a more intellectual track by the officer corps of the Navy. In it Mahan argued for a broader educational approach as opposed to narrow "scientific" and "materialist" approaches to educating an officer corps for the new (but not yet built) navy. ${ }^{15}$

Significantly the second prize essay by Lieutenant Commander C.F. Goodrich reflected the real awareness by the officer corps (at least those involved with the Institute) of the problem facing them as regards the traditional attitudes of Americans towards the

12 From U.S. Naval Institute Constitution and By-Laws, 27 April 2010; for the stages of professionalization see Ronald Spector's discussion, Professors at War, n.11, 152.

13 Arlington National Cemetery, http://www.arlingtoncemetery.net/dammen.htm (accessed 7/26/2011).

14 Daniel Ammen, "The Purposes of a Navy, and the Best Methods of Rendering it Efficient," in The Record (later the Proceedings) of the United States Naval Institute, vol. V, no. 4, 119130 (hereafter Proceedings, vol. \& no.)

15 A.T. Mahan, letter to Samuel A. Ashe, 9 May 1879 from Letters and Papers of Alfred Thayer Mahan, Vol. I, 1847-1889, eds. Robert Seager II and Doris D. Maguire (Annapolis, MD: Naval Institute Press, 1975), 474-476 (hereafter Mahan Papers and volume). Mahan wrote, "Last year as the Institute was growing feeble we determined as a last resort to offer a money prize for an Essay on the subject of Naval Education." See also Love, 330 and, Jon T. Sumida, Inventing Grand Strategy and Teaching Command: The Classic Works of Alfred Thayer Mahan Reconsidered (Washington, D.C.: Woodrow Wilson Center Press/Johns Hopkins Univ. Press, 1997), 16-18. 
military. Goodrich wrote, "The American people, as a natural deduction from their keen love of liberty, have ever cherished an equally keen antipathy to a large standing army and navy." All three prize winning essays were discussed in Annapolis on 10 April 1879 at a meeting with Professor J. Russell Soley as chairman — whose significance will soon be apparent. ${ }^{16}$

In the 1880s the reformist spirit within the Navy found practical expression in two ways - organizationally and the construction of a new generation of modern steam warships. These initiatives were catalyzed via the mechanism of an ad hoc Naval Advisory Board established by Secretary of the Navy William Hunt in 1881. This Board unofficially became known as the Rodgers Board, named after Rear Admiral John Rodgers who presided over it. ${ }^{17}$ The building of the new warships has been discussed adequately elsewhere in the literature and encompassed the so called "ABCD" ships during the Chester Arthur administration. The organizational group of improvements proved more significant and encompassed the ongoing professionalization and modernization of the officer corps via the agency of military education (as advocated by Mahan, Ammen, and others) and other organizational innovations by and within the various Boards and Bureaus. ${ }^{18}$

The organizational reforms enacted during the 1880s were probably more profound than the technological advances. They show the agency of several reformist officers at work, sponsored in part by the towering figure of Admiral Porter. The Rodgers Board's recommendations led to the language in approved Congressional legislation (1882) that provided for two seemingly short term organizational initiatives. The first allowed the Secretary of the Navy to establish a second Naval Advisory Board to continue to meet and recommend more reforms. The second established a Board of Inspection and Survey created to examine both new construction ships as well as to examine the retention of older vessels. By now the dynamic William E. Chandler had become Secretary of the Navy and a cabal of reformers was emerging who were pushing for a system modeled on that of the Prusso-Germans with their Kriegsakademie (War College) and Großer Generalstab (Great General Staff). In addition to Porter and Rodgers, the reformers comprised a younger group of officers that included Captain John G. Walker (Chief of the Bureau of Navigation), Commodore Stephen B. Luce, Commander Henry C. Taylor, and, of course, Commander A.T. Mahan. Of these officers Luce was the most adamant in advocating for the establishment of a professional school along Prusso-German lines - a war college. All of them saw a study of military and naval history as a means to establish sound strategic judgment. ${ }^{19}$

16 Proceedings, vol. V (1879) 323, 377. Volume numbers were not listed between No. 4 until No. 9 and mostly encompassed the first prize essays as well as the extended discussion of them facilitated by Professor Soley.

17 Beers, 45-48.

18 Love, 350-352. ABCD stood for the names of the ships appropriated for by Congress as a result of the Rodgers Board - the unarmored cruisers Atlanta, Boston, and Chicago and the dispatch boat Dolphin (Dolphin later served as the Presidential Yacht). See also Ammen and A.T. Mahan "Naval Education,” Proceedings, vol. V (1879), 345-376.

19 Captain Henry C. Taylor, "Memorandum on General Staff for the U.S. Navy," Proceedings, vol. XXVI, no. 3 (September 1900), 441-445; see also Spector, 14-17. Taylor discusses the 
At the Bureau of Navigation Captain Walker had taken advantage of the spirit of the times in 1882 to act on existing guidance from 1869 to establish an Office of Intelligence inside his Bureau "for the purpose of collecting and recording such naval information as may be useful to the Department in time of war, as well as in peace." 20 This organization soon became known as the Office of Naval Intelligence (ONI) while at the same time a mechanism for the collection of information and intelligence abroad occurred with the dispatch of the first naval attaches on overseas assignments. The Navy Department library was attached to ONI by the same Navy general order to assist its research and nascent war planning function. Professor J. Russell Solely, an activist member of the Institute and soon a lecturer at the Naval War College, was appointed librarian and appropriations made for the purchase and production of books. Among these books were a three volume set on the operations of the Navy during the Civil War published by Charles Scribner's Sons-Soley authored the first volume, A.T. Mahan the second, and Admiral Ammen, the third. ${ }^{21}$ To some degree Soley had subtly transformed the departmental library into a historical research section to support the war plans function inside ONI.

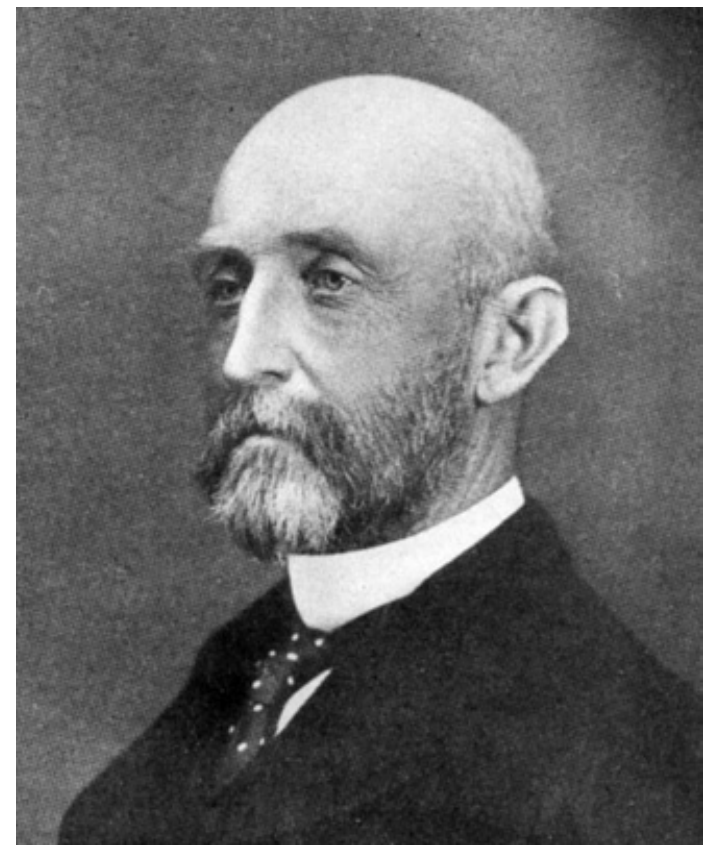

Illustration 2: Alfred Thayer Mahan. Courtesy the Naval Marine Archive.

Concurrently with these developments, the second Naval Advisory Board was established in 1884 by Chandler, this time with Commodore Luce as president with specific direction to investigate the establishment of a Naval War College. Meeting from May to October Luce's Board, not unsurprisingly, found that a Naval War College was

German influence in this famous memorandum he wrote for the Secretary of Navy in the winter of 1899-1900. Interestingly, officers like Luce and Taylor had derived their knowledge about the German system from their counterparts in the Army, Luce from Emory Upton when he had served on the faculty at Fort Monroe's Artillery School. Upton had made a firm study of the German system during an extended visit to Europe in the 1870s and published a book, The Armies of Asia and Europe, that extolled the German system for its superior merits in studying war systematically. Taylor, on the other hand, probably got much of his initial exposure from his fellow faculty member at NWC, Lieutenant Tasker Bliss. See also Beers, 45-4; Sumida, 19-21; Spector, 27-29.

20 Navy Department, General Order No. 292, 23 March 1882, from M.S. Thompson, General Orders and Circulars Issued by the Navy Department from 1863 to 1887 (Washington, 1887), 208.

21 A.T. Mahan, The Gulf and Inland Waters, Volume III (New York: Charles Scribner's Sons, 1883), 269. Soley wrote on the blockade and the cruisers and Ammen addressed the Atlantic theater; Beers, 47-48; for more on Ammen see Spector, 19. 
indeed in the best interests of the nation and the service. With this favorable report Chandler issued an order establishing a college under the Bureau of Navigation at Coaster's Harbor Island in Newport, Rhode Island next to the Torpedo Station. There was no money until 1885 for operation so the Naval War College did not formally open until that year. It was intended to be "combined" (joint in today's language) with active navy, army (Lieutenant Tasker Bliss), and civilian professors (like Soley) lecturing. Luce had barely begun operations when he was ordered back to sea and one of his incoming history lecturers succeeded him as President-A.T. Mahan. ${ }^{22}$

Under Mahan's leadership the college grew in stature and came to include a war planning function as well. The college closed for two years in the late 1880s as it became a source of contention between the powerful Bureaus of Ordnance and Navigation. However, in 1890, with the re-establishment of the office of the Assistant Secretary of the Navy and appointment of Soley to that position, the war planning functions of both College and ONI moved from Navigation under Soley's office. 1890 was a key year since it also included publication of Turner's frontier thesis essay and Mahan's even more influential The Influence of Seapower Upon History, 1660-1783. ${ }^{23}$ A pattern seemed to be emerging wherein these war planning organizations and functions moved under the authority of whoever would make best use of them. However, officers like Taylor still longed for a more permanent general staff type organization to coordinate unified planning.

It is worth reviewing and discussing these events. The decade from 1880-1890 had seen a pace of organizational and structural change and modernization like no other in the Navy's history to that point. It could be argued that a period of comparable reform has not occurred since. The Navy leadership had embarked on a highly technical modernization of its fleet while establishing the first higher level educational institution to study war in the United States. These reformers had established a war planning "shop" inside the Office of Naval Intelligence as well as establishing a system to collect human intelligence overseas. At the same time they created a historical section using the department's library and sponsored, or written themselves, several scholarly and operational works culminating in the most influential book about sea power of all time. The Navy had embraced the new technologies of warship design, although not without some stops and starts while using the Board of Inspection and Survey (eventually the Board of Construction) to streamline the fleet.

However, the final organizational solution had not been adopted. The war planning function was shared by two sub-organizations, the Naval War College and the Office of Naval Intelligence with the Navy Department Library sometimes attached. Mahan and the later historian Henry C. Beers both noted how a reactionary or anti-reform chief of Navigation could muck up the system. Such occurred when Commodore Francis Ramsay succeeded the more enlightened Walker at Navigation and provides an example of why organizational stability was needed. The arrival of the dynamic reformer Soley as the reconstituted Assistant Secretary of the Navy resulted in his bringing all these pieces

22 Beers, 48-50. See also Spector 27-29; Spector gives Bliss the credit for passing on to his naval colleagues the comparative method of historical analysis. .Bliss was later a founder and first president of the Army War College. See also note 19.

23 For a concise discussion of Mahan's influence see Sumida 1-8; Beers, 48-51. 
back under his authority, hearkening back to the proto-CNO actions of Fox during the Civil War except with a somewhat permanent infrastructure now in place. However by 1901 the college and ONI were again under the Bureau of Navigation, but by that time a hoped for solution was already in place to provide war planning continuity - the General Board of the Navy. ${ }^{24}$

\section{Enlightened Interregnum}

From 1891 to 1898, with Mahan, Goodrich, and Henry Taylor in Newport and Soley as Assistant Secretary, this ad hoc system was stable and as a result it thrived. This interregnum provided a period of consolidation for the reforms and new organizations created as a result. It was during this period that Mahan's fame and that of the Naval War College were often conflated with each other. Mahan was correct in pointing out to Luce that his success was outweighed by the education of officers for war at Newport. ${ }^{25}$ Sometimes success has the unintended consequence of obscuring important original objectives. To what purpose was the new American fleet — now acquiring battleships like every other navy and studying war in a serious and systematic fashion - to be put to?

Writers on innovation have always emphasized that the more evolutionary and lasting changes often occur within organizational and institutional contexts when leaders build on the foundations laid by others by getting what is now known as "buy in" by the larger institutional constituency. This is very much what took place in the officer corps of the Navy during the 1890s. ${ }^{26}$ It was also during this time frame that naval leaders laid the groundwork for a second phase of reform. Captain Henry C. Taylor, a faculty member at the College even before Mahan, emerges in this period as another key agent of reform. ${ }^{27}$ Taylor was not alone in his efforts; however, as a member of the Naval Institute and from his perch as the Bureau Chief at Navigation as well as President of the Naval War College, he was ideally positioned to both proclaim the gospel of organizational reform leading to a general staff as well as to support others whose vision was congruent with his. A fine example of him doing both occurred in 1894 when another of the reformers Commander French E. Chadwick presented his paper to the Institute at Annapolis on "Naval Department Organization." Chadwick, it should be noted, was both a confidant and friend of Mahan's as well as having the distinction of being the first (and for a time the only) of the naval attaches (in London) created to support ONI when it was first constituted by Walker. Chadwick had seen much of the world and brought an intimate knowledge of other nations' organizational structures to the paper he presented. $\mathrm{He}$ would later assume the Presidency of the College during the first three years of the General Board's existence from 1900-1903. At the time he presented the paper he was a

$24 \quad$ Mahan Papers, vol. II, Mahan to Luce 26 December 1891, 60-61; Beers, 50-51.

25 Mahan Papers, vol. II, Mahan to Luce 26 December 1891, 60-61. Mahan, alludes to this in his letter to Luce and emphasizes that the NWC is about developing a "group of officers" to practice and prepare for war, not as a launching pad for his own fame.

26 See especially the discussion by Williamson Murray and Barry Watts, "Military Innovation in Peacetime," in Military Innovation in the Interwar Period (Cambridge, MA: Cambridge University Press, 1996), 383-405, and John T. Kuehn, Agents of Innovation (Annapolis, MD: Naval Institute Press, 2008), 3-6.

27 Spector, 27. Taylor paid his own way to Newport in order to teach for inaugural class at the College. 
chief in his own right at the Bureau of Equipment. ${ }^{28}$ Taylor was in attendance and at the time serving as the President of the Naval War College.

The main purpose for Chadwick's paper was to argue primarily for a much simplified structure for the Department. The paper remains valuable for its concise organizational history of the Navy to its state at the time of Chadwick's paper. In it he refers to former Assistant Secretary Fox as a "Chief of Staff" and emphasized Fox's experience as a naval officer in lauding the first Assistant Secretary's "efficient" performance as such. He then reviewed the current organizational state of the Navy as promulgated by the 1891 law that had re-established the office of the Assistant Secretary. In his review he highlighted that "An Office of Naval Intelligence has been established... [but] does not exist by mandate of law, but was formed as a necessity. Elsewhere it is regarded as an essential part of a general staff, and it would at once drop into its proper place in the event of a war, necessity bringing a result in our case which is arrived at elsewhere by foresight bred of the imminency of war." [emphasis mine] He then criticized in the most strenuous terms the authors of the law as creating an organization of "unsurpassed crudity" and of thoughtlessness due to no systematic study of "administrative systems." The point here, of course, is that the reformers were by no means satisfied and realized that what had been done could be undone by the same political winds and processes that had blown after the Civil War. ${ }^{29}$

Chadwick advocated reorganizing the current system of Bureaus and offices into four main sub-organizations underneath the authority of the secretary: a General Staff, a Bureau of Personnel, Bureau of Pay and Accounts, and then an extremely large organization under a "Superintendant of Material." ${ }^{30}$ This last organization would cover the functions of Ordnance, Construction, Steam Engineering, Equipment, General Stores, Provisions and Clothing, and Public Works. The main effort of the paper was a discussion of this new super sub-organization for material and the higher level relationships and lines of authority between them all. Chadwick provided detailed sketches of both the British and French naval organizations, clearly favoring the British template. In addition to the four major organizations he advocated two additional independent boards, one of inspection and another "on Construction." These two bodies were to have watchdog functions and thus independence. Above all this and integrating it all at the policy level with the Secretary he recommended a body composed of all the heads of these organizations that he entitled "The Naval Council" that would also include the most senior admiral not afloat. In his codicil to his annotation for the Naval Council on his line diagram he wrote: "If matters not military be discussed the officer in the Navy

28 F.E. Chadwick, "Naval Department Reorganization," Proceedings, vol. XX, no. 3 (1894), 493-525, discussion of the paper by institute member inclusive. See also Charles O. Paullin, Paullin's History of Naval Administration, 1775-1911 (Annapolis, MD: Naval Institute Press, 1968, essay originally published in Proceedings between 1905-1914), 371; see also Mahan Papers, vol. II, 60, wherein Mahan confides his thoughts on the NWC with Chadwick on a train ride to New York. For NWC Presidents see http://www.usnwc.edu/About/History.aspx (accessed 07/26/2011).

29 Chadwick, 493-499.

30 Formal noun usage is retained here from Chadwick, 500-501, and his accompanying diagram (no page number, it was a fold out insert in that issue). 
Department representing each corps affected by the discussion to be a temporary member." Henry Taylor took this all in and in it we see both a vision of the future in the final make-up of the General Board as well as an attempt to decrease the power of the existing bureaus by making them third tier organizations under the four super bureaus. ${ }^{31}$

As for the future form of the General Board, the codicil discussed above about the Council bears a very strong resemblance to the final mature form that the hearings of the General Board eventually took to include the attendance of the Secretary and Assistant Secretaries at meetings. ${ }^{32}$ As for the General Staff, the relatively small amount of space devoted in the paper to its discussion is instructive by this absence of an existential argument. It is simply taken for granted and given primacy of place in the sketch directly under the Secretary of the Navy (with no Assistant in between) and with the Naval Council description directly underneath it. Position matters. Chadwick assumes his audience was of the same mind as he about the necessity for it given his introductory history of the dysfunction of the Navy in lacking for one. It is worth reviewing his short description of it in the paper:

\section{THE GENERAL STAFF}

The movements of the fleet; inspection of ships [in commission]; preparation of plan of campaign; the Intelligence Office; naval attaches; the receipt and sending out of all communications from and to ships in commission; all orders to officers affecting ships in commission to pass through the General Staff; all correspondence from ships necessary to go to the Superintendent of Material to be forwarded to the General Staff. ${ }^{33}$

Clearly the outline of the future functions and form of the office of the Chief of Naval Operations (CNO) can be seen in this description, although it would take twenty years to get there. However, as a blueprint for the fleet, most of these functions, with the significant exception of the subordination of the bureaus, would come about with the creation first of the General Board (the Naval Council) and then the office of the Chief of Naval Operations (OpNav).

The comments on the paper are as illustrative of the zeitgeist in the officer corps as the paper itself. In these sessions of the Institute the sitting chairman always spoke first and Taylor lauded Chadwick's paper as "excellent," "methodized and systematic." He then presumed to speak for all present, announcing, "I think we all recognize a great loss of effective power in a departmental system which, while dividing the work among the various...bureaus...does not provide for their conjoint united effectiveness." He then essentially re-iterated Chadwick's points about the effectiveness of Fox before addressing his first mild criticism. Significantly Chadwick had left out a discussion of where the NWC fit into his scheme. Since it currently resided with ONI under the Assistant Secretary, Chadwick left it out inadvertently and his comments about ONI applied equally to NWC and he acknowledged as much in his final response after the others had commented. Taylor simply stated that "it might be well to insert the Naval War College,

31 Chadwick, 493-506 and diagram.

32 See discussion in Kuehn, 15-21.

33 Chadwick, 502. 
which in conjunction with the Office of Naval Intelligence, will, it is hoped, in the future do much toward the efficiency of the General Staff." ${ }^{34}$

The other comments on the paper focused mostly on the idea of a super chief of material and the various smaller proposals underneath it for improvements to the functions of the existing bureaus that would be subsumed by such. Significantly, Naval Constructors D.W. Taylor and Francis T. Bowles were dissenting voices on this point. Taylor acknowledged that a "full discussion" was needed and that the paper was valuable. He found the idea of a Naval Council "superfluous" and emphasized the authority and flexibility of navy secretaries to consult whomever they wished whenever they wished. Taylor presented an articulate defense of retention of the bureau system, but with improvements. His opinion on a general staff probably falls under the rule of silence is consent, either that or he did not consider himself qualified to venture an opinion - given Taylor's stature and importance the former is probably a more correct assessment of his position. Bowles brought up the issue of the civil military relationship and favored the status quo with an activist and involved Assistant Secretary. ${ }^{35}$ As to the remainder of the comments about the idea of the General Staff, this was the one area where consensus for its creation was universal, at least at that particular session of the Institute. ${ }^{36}$

Chadwick received the last word and his first words emphasized that he had expected more discussion of what he called the "military phase of the scheme" and highlighted that it was "the primal question in any proper scheme of naval administration. That the establishment of the military part...into a General Staff and a Bureau of Personnel... is in full accord with the consensus of all opinion...within the last ten or twelve years, and in accord with the practice of at least four of the most important military nations." ${ }^{37}$ It may seem here that Chadwick and Taylor were "preaching to the choir," but often times individuals and groups, once they have declared themselves publicly — or not declared themselves publicly — gain a deeper commitment to a particular reform. In this case the issue of the General Staff appears to be assuming the character of a sine qua non for any further naval reorganization. What was needed now was a catalyst. Just as forecast in Chadwick's paper, that catalyst was the war with Spain.

We can now turn back to Walter Millis to find the interaction between a modernizing and professionalizing U.S. Navy and the major events and personalities of the day. If Mahan's geopolitical suppositions regarding the importance of trade routes and geographic position were correct, then it seems no accident that the mid-1890s gave meaning, purpose, and validation to the naval reforms of the 1880s. ${ }^{38}$ It was during this second decade that U.S. policy pronouncements became more and more strident, bombastic even.

The first such incident involved the government of Chile and provided a preview of Chadwick's claim that the "imminency of war" would result in reform. The crew of

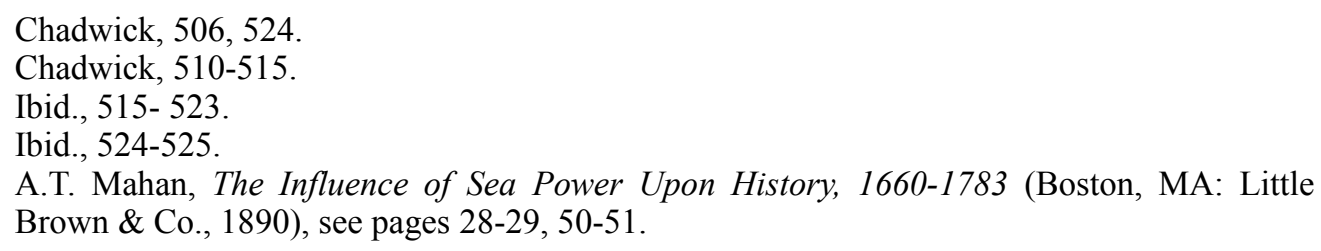


the Baltimore had been attacked by a mob at Valparaiso on 16 October $1891 .{ }^{39}$ Secretary of the Navy Tracy had come to rely on Mahan for advice, in part through the good offices of the ailing Admiral Porter. Mahan had managed to get the NWC reopened after two years, again mostly due to his friendship with Tracy (and support by Porter, Soley, and Luce). When the Baltimore incident occurred Tracy called Mahan to Washington and in concert with Soley and Chadwick began planning for war with Chile using an ad hoc Naval Strategy Board. By January of 1892 the Chileans had apologized, and the Board, now augmented by Bureau Chiefs Ramsay (a Mahan nemesis) and William Folger, was disbanded. No permanent war planning system was established, but on the positive side the precedent of recognizing that the expertise was to be obtained through ONI and NWC had been demonstrated. These were the de facto repositories for war planning expertise. Mahan, in his important December 1891 letter to Luce emphasized that more than himself was needed, that there was a "necessity of gathering a group of officers who may cover the whole ground." In the same letter Mahan emphasized the need to appoint another President in his absence while the planning ("the work") took place in Washington, not knowing how soon the incident would be resolved. ${ }^{40}$

On the larger stage, Great Britain was in a period of strategic transformation-in today's language we would say that her "strategic threat assessment" had changed. The long Pax Britannica at sea had been challenged, tactically and culturally by the Jeune Ecole movement involving the new torpedo boat and soon the "submarine boat" technologies; geopolitically with the emergence of new naval powers such as the German Reich, Empire of Japan, and the United States, and internally by reformers as well as by pacifists. ${ }^{41}$ Even the "pacific" Cleveland administration in the United States could display a rather Mahanian maritime martial spirit in its diplomatic language when conflict arose in the Western Hemisphere in 1895 with Britain over a boundary dispute with Venezuela:

The United States is practically sovereign on this continent and its fiat is law upon the subjects to which it confines its interposition. Why? It is not because of the pure friendship or good-will for it. It is not simply by reason of its high character as a civilized state, nor because wisdom and equity are the invariable characteristics of the dealings of the United States. It is because in addition to all other grounds its

$39 \quad$ Love, 365-368.

40 Mahan Papers, vol. II, 60-61. See also Mahan to Luce, 24 November 1891, 56-57; this letter mentions Chadwick's work on the Board as well as Mahan's recommendation that he replace Mahan should Mahan be ordered to sea pursuant to a war with Chile. Mahan's overriding concern in these letters was the future of the Naval War College. See also Beers, 53.

${ }_{41}$ For a discussion of the Jeune Ecole see Nicholas A. Lambert, "Admiral Sir John Fisher and the Concept of Flotilla Defence, 1904-1909," The Journal of Military History, vol. 59, no. 4 (Oct., 1995), 655-656; for an overview of the transformation of the "Pax Brittanica" see Peter Padfield, Maritime Dominion and the Triumph of the Free World: Naval Campaigns that Shaped the Modern World 1852-2001 (New York: The Overlook Press, 2009), chapter 5 passim. For British attempts to reconcile new technology see Alan H. Burgoyne, "The Future of the Submarine Boat" presented to the Royal United Services Institute, 08 June 1904 with Sir W. White (Late Assistant Controller and Director of Naval Construction) in the Chair, RUSI Journal, vol. XLVIII (July to December 1904), 1288-1311, discussion with Institute members inclusive, including Admiral Sir E.R. Fremantle. 
infinite resources combined with its isolated position render it master of the situation and practically invulnerable against any and all other powers.

Lest the maritime threat inherent in this synthesis of the Melian Dialog and the future Sir Julian Corbett not be apparent, President Cleveland referred to his Secretary of State's missive as "Olney's twenty-inch gun." 42 It seems that now the U.S. had the means and the will, prior even to the Roosevelt Corollary, to bluster enforcement of the Monroe Doctrine across the seas, at least when British and American interests diverged slightly.

By the time the McKinley administration was firmly in the saddle, with Mahan's pen pal Theodore Roosevelt as Assistant Secretary of the Navy, all the pieces seemed to be in place for reform-yet the catalyzing event of war had yet to occur. With the explosion of the Maine and the "martial spirit" animated, this now happened. ${ }^{43}$ Even so reform may not have come so quickly had not Secretary John D. Long had all but relinquished his every duty to his young, dynamic, and navalist historian-assistant. Roosevelt's early actions were indeed dynamic enough to honor the memory of Fox and even garner the praise of Millis. ${ }^{44}$ However, Roosevelt, not to be denied the opportunity for patriotic glory, and perhaps to atone for his father's failure to serve in the Civil War, abdicated his post as proto-chief of the naval general staff leaving a real planning vacuum in his wake. It could not have turned out better for the reformers. The result was the Naval War Board, formed from an existing ad hoc board formed prior to hostilities and composed of the commander-in-chief of the North Atlantic Fleet (Rear Admiral Montgomery Sicard), the heads of Navigation and Ordnance, personnel from the NWC, and the Chief Intelligence Officer. With the outbreak of war Long appointed the Naval War Board composed of the Assistant Secretary of the Navy (Roosevelt), Sicard, three captains (one chief of Navigation), and the head of ONI. Roosevelt and two others soon departed at which point Long ordered Mahan, now retired, in on 9 May $1898 .{ }^{45}$ Meanwhile, as all the talent went to sea, the Naval War College closed for a period of seven months during the war, reopening that November-eliminating the option of using its students and faculty as a planning staff.

The very next day Mahan wrote Long recommending the "Board of War' be abolished, and that in place of it...there be appointed a single officer, to be known by such title as may seem convenient to designate his duties." Chief of Staff, perhaps? He further allowed that this officer pick his own "assistants." Here Mahan's dedication to the Jominian virtue of unity of command as well as his dislike of councils of war and consensus decision-making is firmly on display. ${ }^{46}$ Long ignored this advice, but retained Mahan, although he had not much confidence in his abilities. By this time the Board consisted of just Sicard, Captain A.S. Crowninshield of Navigation, Mahan, and a secretary. Luce, too, vented his own frustration that the war had not led to the permanent establishment of a general staff, although he bore the Board's members no ill will, it was

42 Cited in Millis, 33; for the Melian Dialogue see Thucydides, The Peloponnesian War, trans. Thomas Hobbes with notes and editing by David Grene (Chicago: University of Chicago Press, 1989), 89:365.

43 Millis, 107-145.

44 Millis, 112-113, 121.

45 Beers, 53.

46 Mahan Papers, vol. II, Mahan to Long 9 May 1898, 551-552. 
the ad hoc organizational approach that so irritated him. In the event the Board's recommendations were acted on faithfully by Long and judged practical by at least one

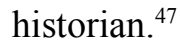

After the war was over Long quickly disestablished the Board. Mahan later recalled the work of the Board in a memorandum to the General Board of the Navy. In that document his ill will toward the process of its creation is apparent, however his judgment as to its purpose and effectiveness is less harsh. He specifically mentioned that Long subsequently said he needed it because he lacked a "General Staff" and that "the authority of a General Staff designate exactly that exercised by the body...in its relations to the head of the Navy Department." [emphasis original] Throughout the lengthy memorandum he emphasizes that the board performed as efficiently and effectively as it did primarily due to the members' knowledge "of the leading principles of war, and..." here Mahan again takes to task the lack of a standing general staff "without previous mature considerations of the effect of this or that disposition on the whole theater of war, - of the relations of the parts to the whole." He closed by estimating that they were lucky the war was short and the enemy less efficient, implying that had it not been so "there could not but be mistakes, which careful previous study would have prevented." It is a lawyerly document, defending his and the Board's work while at the same time criticizing the process and the organizational foundations for it. ${ }^{48}$

One must give due credit to John D. Long, this experience had made him pliable for further reform. Again the indefatigable Henry Taylor enters upon the stage. After serving at the Naval War College Taylor had gone on to command one of the new predreadnought battleships Indiana through the period of the war. In 1899 Long offered him appointment to Annapolis as superintendent, but Taylor turned the job down. $\mathrm{He}$ informed Long he wanted a "less demanding" job so he could advocate for the development of a general staff. Long eventually gave Taylor his shot and asked him to summarize his thoughts about a general staff and submit them to him. ${ }^{49}$ Taylor proceeded to write one of the more hardhitting and persuasive memoranda ever received by a Secretary of the Navy. Although only eight pages, he reviewed the genesis for the memo, the justification based on the example of the "effectiveness," "efficiency," and success of the German General Staff, the purposes for such a staff in peace and in war, and finally the rocky experience of the United States in trying to mimic such an organization without creating something permanent. During the course of his discussion he betrayed his own familiarity with the work of "General von Clausewitz, himself a veteran chief of staff"although whether Long had ever heard of Clausewitz at that point is not known. ${ }^{50}$

In addition to his command of the history of the German General Staff and the lack of such an account in U.S. history, Taylor betrayed a talent for bureaucratic button pushing in the way he closed out his polemic. First, prior to his final declarative

$47 \quad$ Beers, 54.

48 Mahan Papers, vol. III, “The Work of the Naval War Board of 1898: A Report to the General Board of the Navy," 29 October 1906, 627-643.

49 Costello, 18-19.

50 Henry C. Taylor, "Memorandum on General Staff for the U.S. Navy," republished in Proceedings, vol. XXVI, No. 3 (September 1900) with introduction of background by the author, 441-448. The reference to Clausewitz is on page 443. 
recommendations, he intimated that "the Secretary for War...has in view a General Staff for the army, under the name and form of a War College... ." In other words, the Army had seen the light and might beat the Navy to the punch in establishing the basis for a more efficient general staff organization. Taylor's prescience about the Root Reforms that led to just that is rather astonishing at this early date, although he might have been getting inside information from his old friend Tasker Bliss who was later appointed as the first President of the Army War College in 1903. At any rate, he appealed as well to the parochialism of the Secretary of the Navy not to be outdone by War. ${ }^{51}$

Taylor catalogued that most of the components already existed, especially ONI and NWC and that recent experience had militated for a general staff. He then listed his major recommendations. He repackaged (or perhaps plagiarized) Chadwick's recommendation for a Naval Council composed of the major bureau heads and commander-in-chief of the fleet (CinCUS). Taylor's "permanent board" would be composed of the NWC and ONI heads and their assistants plus the Chief of the Bureau of Navigation, who would act as the chief of the general staff with the NWC and ONI remaining organizationally underneath him. The officers at the NWC would include at least ten non-navy personnel to include Revenue (Coast Guard), Marine, Army, reserve and militia officers. These officers would spend half their time in studies at NWC and then spend the other half analyzing intelligence and planning at ONI with a swap occurring after four months. At the end of the course of instruction the most suitable of these graduates would go on to serve as faculty or staff at NWC or ONI "whenever sea duty permits." This last set of proposals was among the most progressive and innovative concepts in the memorandum. ${ }^{52}$

Finally, Taylor also, in rather vague language, argued for a formal Board meeting annually in November to consider the work of the general staff that would include the standing board listed above plus the senior officer of the Navy as well as the commander of the North Atlantic Fleet along with their chiefs of staff. During this month they would review the war plans developed by the general staff within Navigation. ${ }^{53}$ The inclusion of these two senior officers was meant to appeal to officers (like Mahan and Taylor) who wanted officers with recent sea going experience to judge the work of the planners as well as to provide a position of authority for Admiral George Dewey, the hero of Manila Bay who had been voted Admiral of the Navy with "lifetime tenure." 54

Taylor was to be disappointed in the result. Long's response to the memorandum was an incremental synthesis of Taylor's recommendations and his own problem of what to do with Dewey. He essentially adopted Taylor's larger second board and placed Dewey in charge as President. Long promulgated General Order No. 544 on 13 March

51 Taylor, 446-447. For a discussion of the Root Reforms see also Semsch, Philip L. "Elihu Root and the General Staff," Military Affairs 27, no. 1 (Spring 1963): 16-27: see also John Keilers, "Soldier and Statesman: Tasker H. Bliss," http://www.army.mil/article/26498/Soldier and_Statesman_Tasker_H_Bliss (accessed 26 February 2012). The Army reformers were employing the same tactic and the example of the Naval War College to get their own general staff.

52 Taylor, 447-448.

53 Ibid.

54 Costello, 19. 
1900 and established a General Board of the Navy. Nonetheless, Long worried that the establishment of a naval general staff would create a direct line from the chief of the general staff to the President, telling Taylor that he was establishing the Board "as an experiment." To avoid this problem Long restricted the statutory powers of the new planning organization. In particular, Admiral Dewey had no authority over either the administrative bureaus or the fleet. The Board simply drafted advice on a range of topics provided by the Secretary. "The purpose of the Board, as stated in the order [No.544], was 'to insure efficient preparation of the fleet in case of war and for the naval defense of the coast." " 56 The reformers were also disappointed in the long held goal of having such an entity established by Congress in formal legislation.

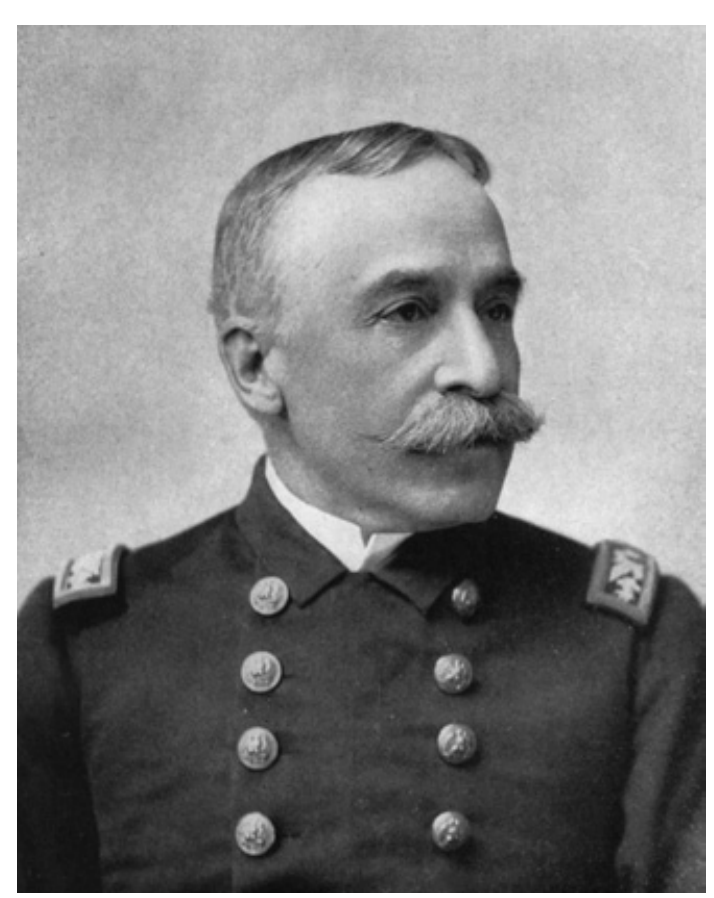

Illustration 3: George Dewey (1837-1913). Courtesy the Naval Marine Archive.

The original membership consisted of the Admiral of the Navy (Dewey), the Chief of the Bureau of Navigation, the Chief Intelligence Officer and his principal assistant, the President of the Naval War College and his principal assistant, and three other officers above the rank of lieutenant commander. The Navigation, NWC and ONI positions were considered "exofficio" positions that would change with their occupancy. The remainder of the members were picked by Long and included two above the three allowed for in the establishing instruction written by Taylor: Taylor, Captain Robely D. "Fighting Bob" Evans, Captain Charles E. Clark, Chadwick (now a captain), and at Taylor's insistence Colonel George C. Reid of the U.S. Marine Corps. Long used the Board's creation to answer those reformers who wanted a planning body, yet its initial mandate was to advise the Secretary only. ${ }^{57}$ As such, the General Board reflected incremental rather than radical military reform of that era in the naval sphere. Nonetheless, the establishment of the General Board was an innovative act, meant to increase the efficiency of the Navy a whole as well as to provide civilian administrations with formal policy and planning advice.

55 Hoover Library (HL), box 156, Memo from General Board (GB) to Assistant Secretary of the Navy dated 14 December 1929. Hereafter HL, GB memo 14 Dec. 1929. See also Love, 417; and Costello, 22.

56 Cited in HL GB memo 14 Dec. 1929. National Archives and Records Administration (NARA) Proceedings and Hearings of the General Board of the U.S. Navy, $1900-1950$ (hereafter PHGB), roll 1 archivist comments.

57 Costello 29. 
Such was the path that led to the establishment of the General Board of the Navy. As a way of suggesting some larger themes and conclusions this compares and coincides with a somewhat similar process that occurred the Royal Navy. The British story is more well known and has generally gone by the name of the "Dreadnought" or "Fisher Revolution." In review, Fisher became the First Sea Lord in 1904-the supreme executive post in the Royal Navy somewhat analogous to the position of Chief of Naval Operations today in the United States. As First Sea Lord Fisher orchestrated a broad series of reforms and naval shipbuilding initiatives resulting in the all big-gun Dreadnought battleship design that obsolesced every existing capital warship. This period saw the complete overhaul of the Royal Navy as an institution and arguably set the stage for Britain's largely successful maritime effort in the First World War (although not without a major unanticipated challenge from submarines) ${ }^{58}$ For comparison with the American reform just reviewed, this paper employs Holger Herwig's model for the components of naval revolution found in Williamson Murray and MacGregor Knox's anthology on military revolution. ${ }^{59}$

Firstly, one must define revolution in a naval or military context. In colloquial terms, lots of change across a broad range of areas in a short space of time-usually preceded by more profound changes of an evolutionary form, "under-the-radar coverage" as it were. Much of what this paper has addressed can be categorized as an evolutionary process. However, the end result proved measurably, evenly radically, different from the situation at the end of the Civil War.

As for revolution, Herwig outlines four principle ingredients in Sir "Jacky" Fisher's stewardship of the Royal Navy as First Sea Lord: "the adaptation of existing technologies" to produce new types of warships, "the reorganization of fleet stations and commands" to serve a new strategy, the reduction of antiquated inventory, and the "recasting of officer education...." 60 In the American case all these elements are mirrored, if not exactly, closely enough to invite comment. Often the technological piece gets first billing and this paper acknowledged, but did not belabor, the modernization efforts during the $1880 \mathrm{~s}$ with the ABCD fleet and then the larger pre-dreadnought battle fleet contracted for in 1890-1891. As a causal factor, Navy officers used the arrival of new modern weaponry in their arguments for the organizational reforms that they held to be most important. Naval technology had become complex and the implications of steam power, torpedoes and other developments demanded a more modern organization founded along the lines of the leading military powers in Europe.

58 Off topic, but for those readers interested in an objective study of Britain's maritime preparedness see Jon T. Sumida, In Defense of Naval Supremacy (New York: Routledge, 1993); those interested in the submarine challenge should consult Gautam Mukunda, "We Cannot Go On: Disruptive Innovation and the First World War Royal Navy," in Security Studies 19, no. 1 (2010), 124-159.

59 Holger H. Herwig, "The battlefleet revolution, 1885-1914," in The Dynamics of Military Revolution, 1300-2050, Macgregor Knox and Williamson Murray eds. (Cambridge UK: Cambridge UP, 2001), 114-131; see also Nicholas Lambert, "Admiral Sir John Fisher and the Concept of Flotilla Defence, 1904-1909," in The Journal of Military History 59 (October 1995), 639-60, for a different interpretation of the Fisher "revolution." 
These organizational reforms matched the changing strategic situation of the United States and took over twenty years to get to the approximation of a general staff as reflected by the establishment of the General Board in 1900. In the case of Great Britain strategic change had impelled revolutionary changes. In the United States it was not so much strategic change, but, as is clear in the testimony of the naval officers offered in this paper, strategic deficit - a deficit of strategic organization to deal with the expanding strategic responsibilities of the United States. From Admiral Ammen in 1879 to Commander Chadwick in 1894, U.S. naval officers foresaw a need to match organization to need a priori to an actual expansion of foreign policy imperatives. Ammen, as we saw, identified the complexity and observed accordingly that "a Navy cannot be improvised." ${ }^{\prime 61}$ Chadwick made a similar point fifteen years later, adding that other "powers dealing with the subject on a much larger scale and under much greater pressure of [the]...prospect of war" had developed proven administrative systems like general staffs to meet their strategic requirements. ${ }^{62}$

In addition to organizing more efficiently to meet the needs of strategy, the officer corps, especially via the mechanism of the U.S. Naval Institute, encouraged intellectual development. This development revolved around the bedrock belief that naval warfare adhered to the more general principles of the art of war and that these were best learned via a "critical" study of military history. The result was not just a method (which actually already existed), but a treatise offering a theory of sea power with a critical historical narrative to illustrate its main points. Mahan provided the theory upon which his fellow professionals could begin their study. ${ }^{63}$ He never meant it to be the final word on sea power, but rather the beginning. He later noted, "so far as they stand the test, my own lectures, form a desirable preparation for works such as those of Corbett...." ${ }^{\prime 4}$

Concurrently with modernization and reorganization, the various boards of inspection accomplished Herwig's third element of reducing a legacy inventory of ageing and obsolete warships - weeding out the deadwood prior to the modern steel and steam fleet. Herwig's final element, that of professional education, is perhaps more striking in the American case, since it provided both the vehicle and the continuity for greater strategic and operational reorganization while at the same time fulfilling the need for a broader professional, and ironically less technically focused, higher education for the Navy's officer corps.

Based on this review one might characterize the period of $1880-1900$ as generally satisfying Herwig's criteria and prefiguring the more flashy and well known "Fisher Revolution." This offers an opportunity to comment upon some differences between the two processes. Whereas the British case had strong elements of a "cult of personality"

Ammen, 119.

Chadwick, 494.

Mahan Papers, vol. II, 7 May 1890, letter to Luce, 10. Mahan writes, "my principal aim has been to write a critical military history of the naval past...." as he explains to Luce his progress on The Influence of Sea Power Upon History, 1660-1783. As for the already existing method, see Carl von Clausewitz, On War, Book II (Princeton, NJ: Princeton University Press, 1984), ed. and trans. Peter Paret and Michael Howard.

64 A.T. Mahan, Naval Strategy (Newport, RI: Department of the Navy), originally published 1909, reprint 1991 as U.S. Marine Corps pub FMFRP 12-32, 19. 
centered on Fisher, that in the United States was more group-oriented and driven by a collective desire for reform beginning modestly with the establishment of an intellectual professional framework with the U.S. Naval Institute. As is so often the case, there was no one hero, but rather many. Oftentimes the focus is on just Mahan, or just Luce, or just Taylor. However, if this paper has suggested anything it is that group dynamics and a strong desire to be efficient drove the effort by the Navy officers of the late $19^{\text {th }}$ century to lift themselves up by their collective bootstraps. They were a rather unlikely band of brothers of the sea - and their intellectual spirit of professional reform changed the Navy in ways that are still worth studying today. This martial spirit naval style led to a U.S. Navy that within a generation became "second to none." ${ }^{65}$

65 The reference here is to the essential rallying cry of the Navy during the Great War for a need of a "Navy Second to None." See Davis, George T. A Navy Second to None: The Development of American Naval Policy, New York, Harcourt Brace \& Co., 1940; and NARA RG80 Proceedings and Hearings of the General Board, 17 January 1925, "U.S. Naval Policy." The 1922 "Naval Policy" is attached to the 1925 General Board hearing transcript. 